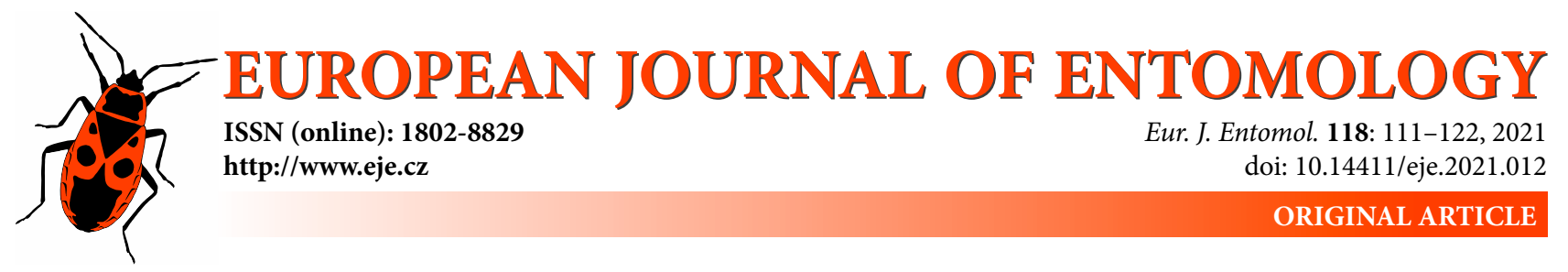

\title{
Similar songs, but different mate localization strategies of the three species of Phaneroptera occurring in Western Europe (Orthoptera: Phaneropteridae)
}

\author{
Klaus-Gerhard Heller ${ }^{1}$, Martina HelleR ${ }^{1}$, Marianne VOlleth $^{1}$, Jörg SAMietz ${ }^{2, *}$ and Claudia HemP ${ }^{3}$ \\ ${ }^{1}$ Grillenstieg 18, 39120 Magdeburg, Germany; e-mail: heller.volleth@t-online.de \\ ${ }^{2}$ Institute of Ecology, Friedrich-Schiller-University Jena, Germany \\ ${ }^{3}$ Department of Plant Systematics, University of Bayreuth, Bayreuth, Germany; e-mail: claudia.hemp@uni-bayreuth.de \\ ORCiD. K.-G. Heller: 0000-0002-3331-3228
}

\begin{abstract}
Key words. Orthoptera, Tettigonioidea, Phaneropteridae, Phaneropterinae, acoustical communication, songs, female response, duetting, mate localization
\end{abstract}

\begin{abstract}
In bush-crickets, males produce a calling song to announce their presence to females. Females ready to mate respond either by a phonotactic approach or signal their presence acoustically by establishing a kind of duet. This duetting behaviour is typical of phaneropterid bush-crickets, of which many species in Europe are flightless. In the long-winged genus Phaneroptera, the females also respond acoustically to the male calling song, which is quite similar in the three west European species in this genus. After acoustical contact, however, the behaviour of males and females of the three species differ markedly. In $P$. nana, males and females engage in a duet in which the female responds to each syllable of the male song (and he approaches her). In $P$. falcata, the female only responds to certain elements of the male song that are produced at long intervals. However, after her response the male does not change its song or its position, but often increases its singing activity (and the female approaches him). In P. sparsa the female only responds to particular, very complicated and soft elements of the male song, which are typically repeated at intervals of several to many minutes. After hearing the response, the male drastically changes its song by producing only the soft elements. These parts of the song contain syllables with a unique spectral composition and others that may threaten eavesdropping rivals. In this species both sexes probably move towards each other during mate localization. At present, we can only speculate about the adaptive nature of the different strategies.
\end{abstract}

\section{INTRODUCTION}

Bush-crickets of the genus Phaneroptera are good flyers and are quite mobile. This capability makes them interesting candidates for studying the effects of climate change in Europe. Two of the three species in western Europe have expanded their distributions quite rapidly in the last few years (e.g. Poniatowski et al., 2018). However, their high mobility is also interesting in terms of their mate finding strategies. As in most tettigonioids, males produce calling songs to announce their presence to the females and the females of at least some of the species of Phaneroptera (Zhantiev \& Korsunovskaya, 1986; Tauber et al., 2001; Samietz et al., 2014) are known to respond acoustically to males. This duetting behaviour is typical of the subfamily Phaneropterinae (Heller et al., 2015) and is described for many European species (e.g., Stumpner \& Meyer, 2001; Heller et al., 2018). Most of the European species, however, are short-winged and flightless. Studies on pair forming behaviour in these species have recognized two basic types, one in which calling males approach acoustically responding females and one in which the females are mute and approach calling males, and there are also species in which both sexes move towards each other (e.g., Zhantiev \& Korsunovskaya, 1986). Among long-winged North American phaneropterids, however, Spooner reports more complicated types of mating behaviour (reviewed in Spooner, 1995). Here the females always produce sounds, but the males use different acoustical signals. Thus, mobile males of Phaneroptera could also use other mate finding strategies, possibly more similar to the ancestral situation reported in long-winged tropical phaneropterines.

Phaneroptera Serville, 1831 is a widespread genus with ca. 36 species occurring nearly everywhere in the tropics of the Old World (Ragge, 1956). In Europe, four species are known. P. spinosa Bey-Bienko, 1954, which occurs only in the East of the continent (westernmost point Danube

\section{* Deceased.}


delta; Iorgu et al., 2008; as P. gracilis Burmeister, 1838). In western Europe, two species, P. falcata (Poda, 1761) and $P$. nana Fieber, 1853, are widely distributed, while the third species, $P$. sparsa Stål, 1857, is only found in parts of the Iberian Peninsula, Madeira and the Canary Islands. This species, however, is widespread in large parts of Africa (Ragge, 1956).

Morphologically the genus Phaneroptera is relatively unspecialized. Ragge (1980) writes "Phaneroptera is a rather nondescript genus, chiefly recognizable from its lack of any striking features." However, it has some peculiar characteristics not mentioned by Ragge. In all the species there are two bends in the middle or distal part of the male stridulatory file ( $P$. falcata, P. nana, P. sparsa, P. brevis Serville, 1838, P. cleomis Ayal, Broza \& Pener, 1973, $P$. gracilis, $P$. minima Brunner von Wattenwyl, 1878, P. myllocerca Ragge, 1956, P. nigroantennata Brunner von Wattenwyl, 1878, P. rentzi Divya \& Senthilkumar, 2020; Ayal et al., 1973; Heller, 1988; Hugel, 2009; Kim, 2009; Liu, 2011; Divya \& Senthilkumar, 2020), and the vertical side of the asymmetrical stridulatory teeth points basally, indicating sound production during wing opening (called reverse stridulation by Montealegre-Z, 2012). Phaneroptera (P. sparsa: Leroy, 1970; P. falcata; P. nana; P. brevis: own unpubl. observ.) is also one of the very few tettigonioid genera not in the Pseudophyllinae in which the non-functional file on right male tegmen is greatly or completely reduced (Chamorro et al., 2014).

$P$. falcata and $P$. nana occur sympatrically in many parts of Europe, $P$. nana and sparsa occur together in Syria, Israel and Madeira (here probably sparsa or both were introduced relatively recently; Ragge, 1956). Although ecologically similar, $P$. falcata and $P$. nana are only occasionally found syntopically. Zuna-Kratky (2017) assumes that $P$. nana prefers more humid habitats than $P$. falcata. Previous studies on the acoustic behaviour of these three species have shown that their songs or at least large parts of them are similar [e.g. Heller, 1988 (but see below); for falcata and nana only: descriptions and recordings of e.g., Bonnet, 1995; Ragge \& Reynolds, 1998; Barataud, 2007; Roesti \& Keist, 2009; Deroussen, 2012; Massa et al., 2012; Kocarek et al., 2013; Gomboc \& Šegula, 2014; Willemse et al., 2018]. These studies have focused mainly on male songs. Only in $P$. nana has the female's behavioural response been analysed in detail (Zhantiev \& Korsunovskaya, 1986, 1990; Tauber et al., 2001). In captivity, P. nana and sparsa could be moved to mate with each other, but do not produce viable offspring (Helfert \& Sänger, 1990).

This study is a detailed comparison of the acoustic behaviour of males and females of all three species.

\section{MATERIAL AND METHODS}

All sound recordings were made in the laboratory. The animals were partly collected as adults, partly as nymphs (all females except one P. nana). P. nana and P. sparsa were also reared from eggs. $P$. falcata was collected near Colbitz and Ballenstedt, both in Sachsen-Anhalt, and in the valley of the river Leutra, near Jena, Thüringen, all in Germany, P. nana in Heidelberg, Germany, and P. sparsa in Príncipe, near Bom Bom Island Resort $\left(1^{\circ} 41^{\prime} \mathrm{N}, 7^{\circ} 24^{\prime} \mathrm{E}, 20 \mathrm{~m}\right.$ a.s.l., São Tomé \& Príncipe (details see Heller, 2019), in Kidia, Mt. Kilimanjaro, Tanzania, and in Minziro Forest Reserve, Bukoba, Tanzania. The location of the sites where the animals used in the comparative morphological study were collected are given in the Appendix. For $P$. falcata songs of 14 males and 13 females were recorded $(70 \mathrm{~h}, 42 \mathrm{~min}$ recordings without female, $118 \mathrm{~h}, 45 \mathrm{~min}$ with female responses), for the well-studied $P$. nana 3 males and 2 females $(19$ h, 34 min recordings without female, $9 \mathrm{~h}, 16 \mathrm{~min}$ with female responses) and for P. sparsa 23 males and 19 females (Príncipe: 60 h, 21 min recordings without female, $39 \mathrm{~h}, 34 \mathrm{~min}$ with female responses, from 19 males, 16 females; Tanzania, Kidia: 37 h, 15 min recordings without female, $11 \mathrm{~h}, 12 \mathrm{~min}$ with female responses, from 3 males, 3 females; Tanzania, Minziro: 2 h, 42 min recordings of one male). The male calling songs were recorded using a digital bat detector (Pettersson D1000X) mostly with a sampling rate of $100 \mathrm{kHz}$ (rarely 192 and $300 \mathrm{kHz}$ ) or with an Uher M645 audio microphone (only for the pattern in amplitude). The singers were caged in plastic tubes or gauze cages with the microphone fixed or hand held at distances between 5 and $60 \mathrm{~cm}$. The female response behaviour was studied using virgin females, reared from field collected nymphs or eggs. Duets were recorded in stereo using a Sony PC-62 microphone (frequency response relatively flat up to $30 \mathrm{kHz}$ according to own tests) and an Uher M645 audio microphone connected to a personal computer through an external soundcard (Transit USB, "M-Audio"; $44.1 \mathrm{kHz}$ or $64 \mathrm{kHz}$ sampling rate). Here males and females were placed separately in two plastic tubes [Drosophila tube $28.5 \times 95 \mathrm{~mm}$, Biosigma, Cona (VE), Italy] mostly standing side by side, with a microphone placed inside or on top of each vial. For some tests the distance between males and females was varied up to a maximum of $2 \mathrm{~m}$. Both microphones typically picked up male and female sounds, but with different amplitudes. Most recordings were made when it was dark, between 0:00 and 3:00 a.m. Song measurements were obtained using Audacity (Audacity 2.1.0; http://audacity.sourceforge.net), Amadeus II and Amadeus Pro (Martin Hairer; http:// www.hairersoft.com). Oscillograms of the songs were prepared using Turbolab (Bressner Technology, Germany) and Audacity. The recordings of the wing movements (Fig. 3A, B, D, F) are taken from data evaluated earlier (see Heller, 1988, also for methods). Most recordings were made at temperatures between 22 and $28^{\circ} \mathrm{C}$. Data are presented as mean \pm standard deviation. For spectral analysis, short song parts $(120 \mathrm{~ms}$ in the male, $30 \mathrm{~ms}$ in the female) were analysed using the mean of 512 point wide Hanning windows, overlapping by 100 points. Here also the recordings of P. falcata mentioned in Heller (1988) were re-evaluated. Sound pressure level measurements were made using a Genrad GR 1988 sound level meter (IET Labs) set to flat frequency response (up to $20 \mathrm{kHz}$ ) and peak reading (in dB SPL $r e 2 \cdot 10^{-4} \mu \mathrm{bar}=2 \mu \mathrm{pa}$ ).

Acoustical terminology. Tettigonioids produce their songs by opening and closing their tegmina. The sound resulting from one cycle of movement is called a syllable, often separable into opening and closing hemisyllables (Ragge \& Reynolds, 1998). Syllable duration: time measured from the beginning of the first impulse to the last; syllable period: time measured from the beginning of a syllable to the beginning of the next (reciprocal value: syllable repetition rate SRR); echeme: first-order assemblage of syllables (duration, period and rate as for syllable); impulse: a simple, undivided, transient train of sound waves; microsyllable: isolated impulse (or small group of impulses) separated from the main impulse of a male syllable, produced by a small amplitude wing-movement; latency time: interval between beginning of male song or of a trigger syllable in the male song (see results) to beginning of female response. 
In addition, the behaviour of several males and females of $P$. falcata kept together in a large cage was recorded on tape for several hours using a video camera (Camcorder LC 295 Grundig) without recording the sounds.

The stridulatory files were photographed using a Sony Cybershot DSC-P120 on an Olympus SZ Binocular Stereo Zoom Microscope dissecting microscope.

\section{RESULTS}

\section{Identification}

Males of $P$. falcata can be easily distinguished from $P$. nana and $P$. sparsa by the shape of their cerci and their differently shaped subgenital plates (e.g., Ragge, 1956; Harz, 1969). The situation with $P$. nana and $P$. sparsa is much more difficult. In 1956, Ragge established both forms as allopatric subspecies, distinguished from each other mainly by the relative length of the fore wings and shape of male cerci. However, the variation in both characters is large with a strong geographical component (see Ragge, 1956, fig. 99). Another complication is that the Armenian form, P. bivittata Bey-Bienko, 1954, was assumed to belong to P. (nana) sparsa (Ragge, 1960). In the first comparative study of the acoustics and stridulatory organs of these species (Heller, 1988) nana and sparsa seemed to differ in the number of stridulatory teeth and the carrier frequency, but not in the amplitude pattern of their songs. However, these results were for an European nana and a 'sparsa' from NE-Turkey. The current data (see below) indicates that the stridulatory organ of 'true' sparsa from Africa does not differ from that of nana. So, in terms of morphology only the characters given by Ragge (1956) are available. In addition to differences in the shape of the cercus these are:
Fore wing-length/hind femur-length ratio more than 1.1, the fore wings usually extending beyond the hind knees. Lateral pronotal lobes deeper than long: P. nana.

Fore wing-length/hind femur-length ratio less than 1.1, the fore wings usually do not reach the hind knees. Lateral pronotal lobes about as long as deep: P. sparsa.

In terms of the ratio of fore wing-length to hind femurlength, all our specimens of $P$. sparsa differed distinctly from the other two in being clearly below the diagnostic value of 1.1 (Table 1). P. bivittata was also under this value.

$P$. sparsa from different areas may also have different songs (see Massa et al., 2010; Naskrecki \& Guta 2019, data below). However, since the song is quite complex and the data in these studies (including the number of animals studied) are mostly very limited, it is not possible to draw any conclusions.

The specimen from NE-Turkey (sparsa in Heller, 1988) is considered to belong to P. bivittata, which supports Stolyarov's (2005) view of an independent species and makes it the first record for Turkey (locality see Heller, 1988 as P. sparsa).

Based on limited material of $P$. bivittata, this species and $P$. nana are similar in the amplitude pattern of their songs, but differ in the structure of their stridulatory files (Fig. 1B, D) and peak frequencies (see Heller, 1988; as nana and sparsa). P. sparsa has a very different song pattern, but a file like that of nana and frequencies as high as those recorded for bivittata. In terms of impulse number, $P$. bivittata is similar to P. falcata and sparsa (see Table 2).

\section{Stridulatory files}

The male stridulatory file in tettigonioids is located on the lower side of the left tegmen. The basal part of the file is near the articulation (in Fig. 1 on the left). From there,

Table 1. Measurements of stridulatory files and body dimensions of species of Phaneroptera. For definition of "half main part" of the stridulatory file see Fig. 1. Specimens photographed in Fig. 1 in bold. Details of the localities see Appendix.

\begin{tabular}{|c|c|c|c|c|c|c|}
\hline Species/\# & Country of origin & $\begin{array}{c}\text { Inter-tooth } \\
\text { distance }(\mu \mathrm{m})\end{array}$ & $\begin{array}{c}\text { Number of teeth on half } \\
\text { of the main part }(n)\end{array}$ & $\begin{array}{c}\text { Length of } \\
\text { tegmen }(\mathrm{mm})\end{array}$ & $\begin{array}{l}\text { Length of hind } \\
\text { femur }(\mathrm{mm})\end{array}$ & $\begin{array}{c}\text { Ratio length } \\
\text { tegmen/hind femur }\end{array}$ \\
\hline \multicolumn{7}{|l|}{ falcata } \\
\hline $\mathrm{CH} 0404$ & Germany & 38.5 & 22 & 21 & 19.0 & 1.11 \\
\hline $\mathrm{CH} 0706 / 7$ & Germany & 40.7 & 19 & 21 & 19.0 & 1.11 \\
\hline CH8589 & Germany & 40.3 & 20 & 20.5 & 18.0 & 1.14 \\
\hline $\mathrm{CH} 7010$ & Poland & 36.7 & 19 & 20.5 & 18.5 & 1.11 \\
\hline $\mathrm{CH} 7402$ & Romania & 40.7 & 18 & 21.5 & 20.0 & 1.08 \\
\hline Kim, 2009, fig. 66 & South Korea & 40.3 & & - & - & - \\
\hline \multicolumn{7}{|l|}{ nana } \\
\hline $\mathrm{CH} 0713$ & Spain & 37.5 & 15 & 18.5 & 15.5 & 1.19 \\
\hline $\mathrm{CH} 0715$ & Italy & 38.4 & 17 & 20.5 & 18.0 & 1.14 \\
\hline CH5489 & Turkey & 31.3 & 19 & 17.5 & 16.0 & 1.09 \\
\hline $\mathrm{CH} 6385$ & Greece & 38.4 & 15 & 20.5 & 18.0 & 1.14 \\
\hline $\mathrm{CH} 8705$ & Germany & 43.5 & 18 & 21.5 & 17.5 & 1.23 \\
\hline \multicolumn{7}{|l|}{ sparsa } \\
\hline CH4958 & Namibia & 34.4 & 18 & 17.5 & 17.0 & 1.03 \\
\hline $\mathrm{CH} 4957$ & Madagascar & 33.6 & 24 & 16.2 & 16.0 & 1.01 \\
\hline CH5002 & Congo & 24.4 & 22 & 16 & 17.7 & 0.90 \\
\hline CH8561 & São Tomé \& Príncipe & 26.4 & 21 & 16 & 17.0 & 0.94 \\
\hline CH8685 & Tanzania & 33.3 & 18 & 16.5 & - & - \\
\hline \multicolumn{7}{|l|}{ bivittata } \\
\hline $\mathrm{CH} 0710$ & Turkey & 21.1 & 33 & 17 & 16.0 & 1.06 \\
\hline \multicolumn{7}{|l|}{ nigroantennata } \\
\hline Kim, 2009, fig. 68 & South Korea & 25.2 & 49 & - & - & - \\
\hline
\end{tabular}



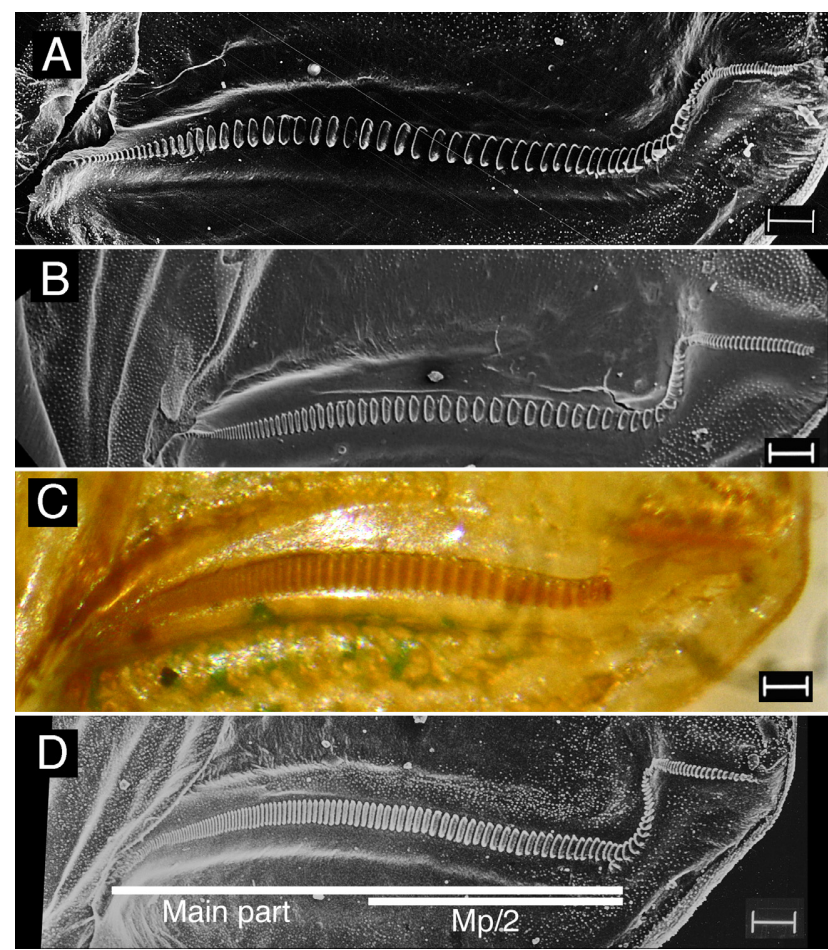

Fig. 1. Photographs of the male stridulatory files of (A) Phaneroptera falcata, (B) P. nana, (C) P. sparsa and (D) P. bivittata (see Table 1 and Appendix for data on the specimens). Scale $100 \mu \mathrm{m}$.

the file extends distally to what is sometimes called the anal part (in Fig. 1 on the right). The stridulatory files of $P$. falcata and $P$. nana are described as very similar by Heller (1988). This refers especially to the long and relatively straight basal part, here called the main part (Mp; see Fig. 1D). The stridulatory file of $P$. sparsa is not obviously different. Only that of $P$. bivittata has a great number of teeth (Table 1). Since the teeth near the articulation are quite small and difficult to count the exact number can only be obtained from scanning electron microscope photographs.
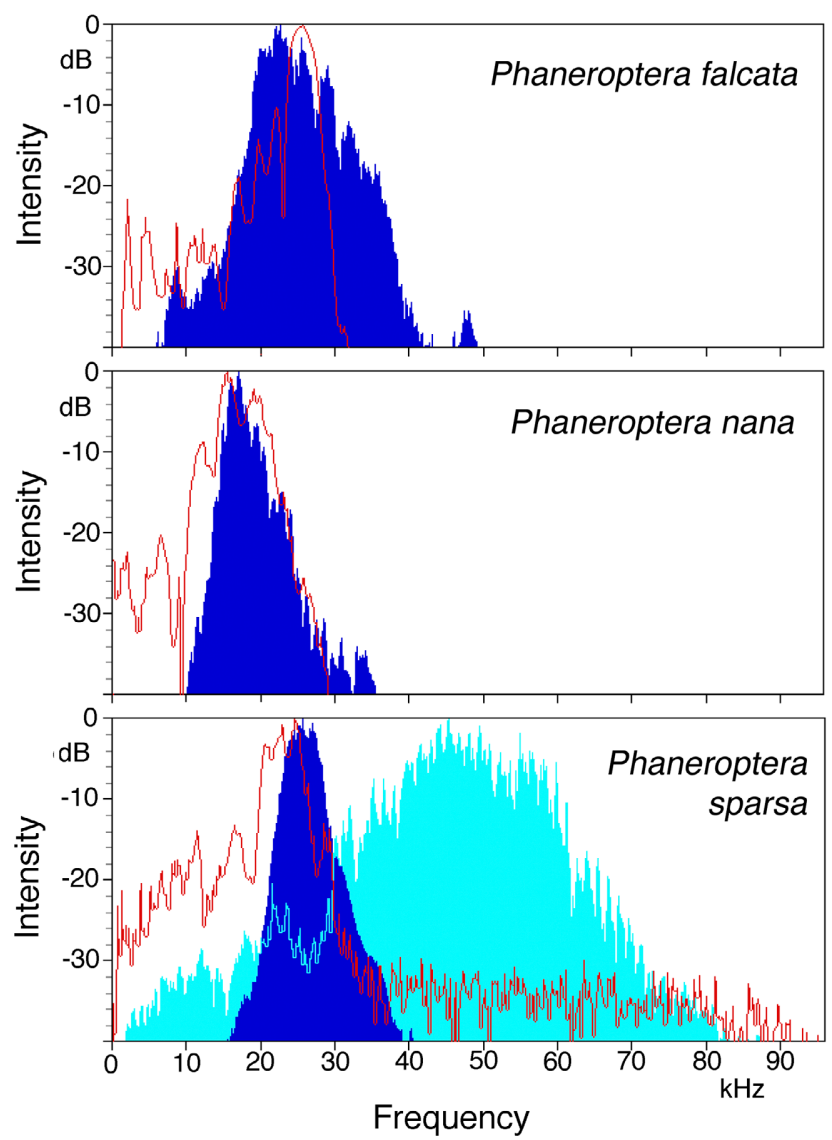

Fig. 2. Power spectra of the male calling song (blue) and female response (red lines) for species of Phaneroptera and of the $50-\mathrm{kHz}-$ syllables produced by $P$. sparsa (light blue).

To obtain comparable data using dissecting microscopes, we measured (1) the distance between two consecutive teeth (mean between 10 most widely spaced teeth) and (2) counted the number of teeth on the distal (= anal) half of the main part (Table 1). The distance between teeth was largest in P. falcata and smallest in P. sparsa, but even in

Table 2. Temporal parameters of male songs of species of Phaneroptera (ranges of data are based on all single measurements).

\begin{tabular}{|c|c|c|c|c|c|c|c|c|c|c|c|}
\hline \multirow[t]{2}{*}{ Species } & \multicolumn{2}{|c|}{ Syllable period (s) } & \multicolumn{2}{|c|}{$\begin{array}{l}\text { Duration of syllable } \\
\text { (ms) }\end{array}$} & \multicolumn{2}{|c|}{$\begin{array}{l}\text { Number of } \\
\text { impulses }\end{array}$} & \multirow{2}{*}{$\begin{array}{c}\text { Impulse } \\
\text { period (ms) } \\
\text { mean }\end{array}$} & \multicolumn{2}{|c|}{$\begin{array}{l}\text { Syllable per } \\
\text { echeme }\end{array}$} & \multirow{2}{*}{$\begin{array}{c}\text { Temperature } \\
\left({ }^{\circ} \mathrm{C}\right)\end{array}$} & \multirow[t]{2}{*}{$\mathrm{n}$} \\
\hline & mean $\pm S D$ & range & mean $\pm S D$ & range & mean $\pm S D$ & range & & mean $\pm S D$ & range & & \\
\hline \multicolumn{12}{|l|}{$\begin{array}{l}\text { Single } \\
\text { syllable }\end{array}$} \\
\hline falcata & $1.8 \pm 0.8$ & $0.1-8.9$ & $57.7 \pm 8.4$ & $30-79$ & $16.3 \pm 3.6$ & $7-24$ & 3.7 & & & $23-26$ & $\begin{array}{l}14 \text { males, } n=10 \text { per } \\
\text { male (only } 7 \text { in one) }\end{array}$ \\
\hline $\begin{array}{l}\text { nana } \\
\text { (dense) }\end{array}$ & $1.6 \pm 0.6$ & $0.7-3.8$ & $42.1 \pm 4.8$ & $30-42$ & $8.0 \pm 2.6$ & $5-13$ & 6.0 & & & $24-28$ & $\begin{array}{c}2 \text { males, } \\
\mathrm{n}=13-15 \text { per male }\end{array}$ \\
\hline $\begin{array}{l}\text { nana } \\
\text { (sparse) }\end{array}$ & $1.4 \pm 0.7$ & $0.4-9.9$ & $62.0 \pm 6.5$ & $36-86$ & $5.0 \pm 0.1$ & $3-19$ & 15.5 & & & $24-28$ & $\begin{array}{c}3 \text { males, } \\
\mathrm{n}=13-30 \text { per male }\end{array}$ \\
\hline $\begin{array}{l}\text { sparsa } \\
\text { Principe }\end{array}$ & $0.4 \pm 0.2$ & $0.1-3.1$ & $63.7 \pm 8.0$ & $40-87$ & $14.4 \pm 2.6$ & $9-21$ & 4.8 & & & $22-26$ & $\begin{array}{c}15 \text { males, } \\
\mathrm{n}=10 \text { per male }\end{array}$ \\
\hline $\begin{array}{l}\text { sparsa } \\
\text { Kidia }\end{array}$ & $1.1 \pm 0.5$ & $0.5-2.1$ & $38.5 \pm 3.2$ & $32-49$ & $9.1 \pm 0.7$ & $7-11$ & 4.8 & & & $22-23$ & $\begin{aligned} & 3 \text { males, } \\
\mathrm{n}= & 10 \text { per male }\end{aligned}$ \\
\hline bivittata & $3.0 \pm 0.5$ & $2.3-3.8$ & $84.4 \pm 4.6$ & $76-92$ & $15.2 \pm 1.5$ & $13-17$ & 5.9 & & & $>27$ & 1 male, $n=10$ \\
\hline \multicolumn{12}{|c|}{$\begin{array}{l}\text { Syllable } \\
\text { in echeme }\end{array}$} \\
\hline falcata & $0.11 \pm 0.01$ & $0.09-0.12$ & $73.5 \pm 3.7$ & $60-87$ & $27.4 \pm 3.7$ & $16-33$ & 2.8 & $12.9 \pm 1.5$ & $7-18$ & $23-26$ & $\begin{array}{c}14 \text { males, } \\
\mathrm{n}=6-14 \text { per male }\end{array}$ \\
\hline $\begin{array}{l}\text { sparsa } \\
\text { Minziro }\end{array}$ & $0.09 \pm 0.01$ & $0.09-0.10$ & $44.4 \pm 3.9$ & $41-52$ & $11.0 \pm 0.8$ & $10-12$ & 4.4 & $8.9 \pm 1.1$ & $7-11$ & 24 & 1 male, $n=10$ \\
\hline
\end{tabular}



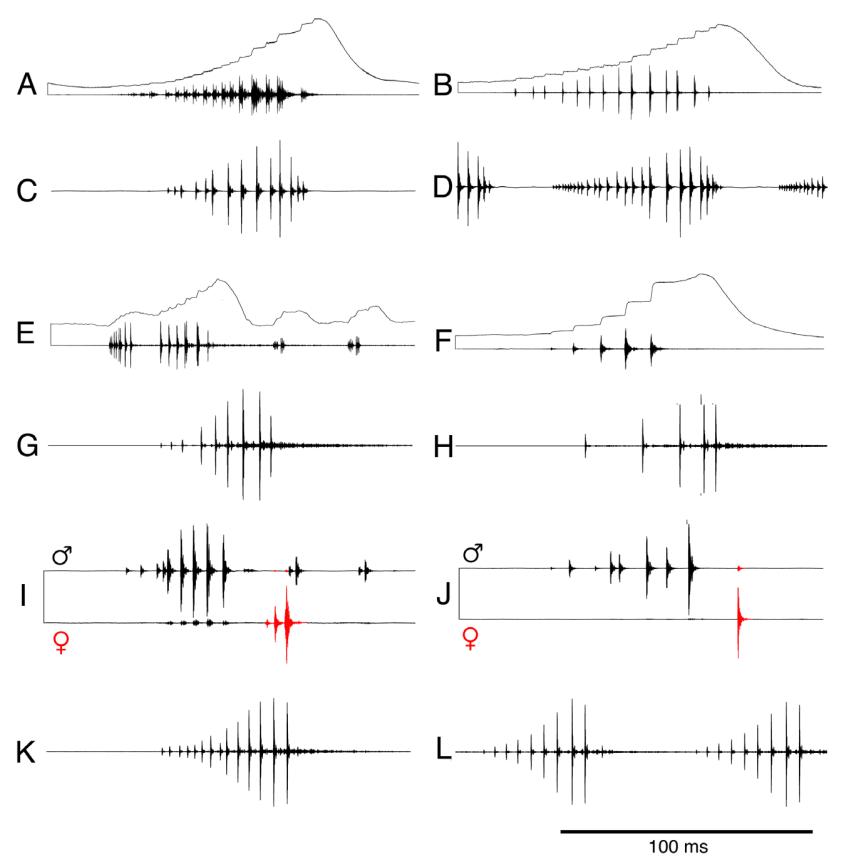

Fig. 3. Oscillograms of stridulatory movement $[A, B, E, F$ only synchronous registration of movement of left tegmen and sound (upper line: upward deflection indicating opening, downward closing; lower line: sound)] and sound of the basic song elements in species of Phaneroptera. A, C, D - P. falcata, B - P. bivittata, E-J - P. nana, $\mathrm{K}-\mathrm{L}-\mathrm{P}$. sparsa. $\mathrm{B}, \mathrm{C}, \mathrm{E}-\mathrm{H}, \mathrm{I}$ - single syllables, $\mathrm{A}, \mathrm{D}$, $\mathrm{L}$ - parts of echemes, I, J - duet. A - note strong echoes, $B$ - note occasional double impulses, E, G, I - dense syllables (E, I with microsyllables), $\mathrm{F}, \mathrm{H}, \mathrm{J}$-sparse syllables, $\mathrm{K}$ - Príncipe population, $\mathrm{L}-$ Tanzania, Minziro population.

these small samples, values for $P$. nana overlapped both of them. P. bivittata has smaller inter-tooth distances than sparsa and clearly more teeth on the distal half of the main part, while the other three species did not differ in this character.

\section{Song}

\section{A) Carrier frequencies}

The spectral properties of the songs of the three species were relatively similar (Fig. 2). Phaneroptera nana had the lowest peak frequency $(16.8 \pm 0.6 \mathrm{kHz}$; bandwidth $10 \mathrm{~dB}$ below peak $5.3 \pm 0.5 \mathrm{kHz}$; three males). P. falcata and $P$. sparsa had higher peak frequencies and $P$. falcata wider bandwidth (P. falcata $24.2 \pm 1.5 \mathrm{kHz}$, bandwidth $12.2 \pm 4.7$ $\mathrm{kHz}$, three males; P. sparsa $26.0 \pm 1.2 \mathrm{kHz}$, bandwidth $6.6 \pm 0.9 \mathrm{kHz}, 8$ males). As far as it can be judged from the limited number of high-frequency recordings, the spectra of the female responses were similar (Fig. 2).

The males of $P$. sparsa occasionally produced short series of (typically containing three soft) syllables with a much higher peak frequency and wider bandwidth (Fig. 2; peak $51.0 \pm 3.9 \mathrm{kHz}$; mid of range $10 \mathrm{~dB}$ below peak $48.0 \pm 5.5$ $\mathrm{kHz}$, bandwidth $25.3 \pm 7.4 \mathrm{kHz}$; 8 males, 2 measurements each) than the typical song. These syllables are referred to as $50-\mathrm{kHz}$-syllables.

\section{B) Amplitude pattern}

In all three species isolated syllables were the most commonly heard song element (not recorded in the song of $P$.

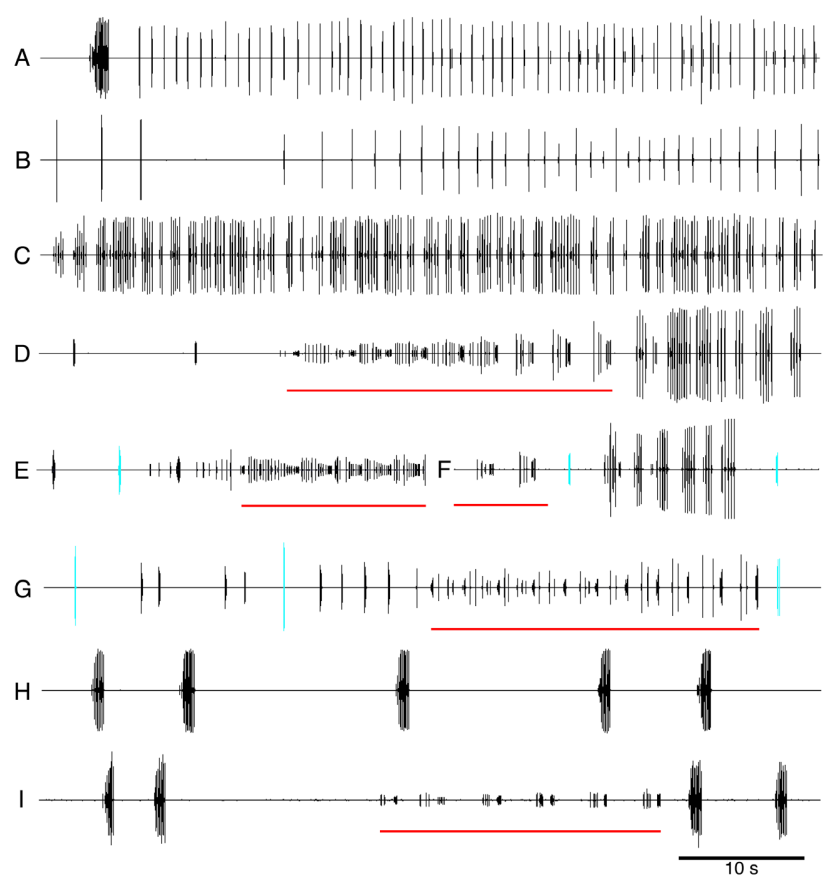

Fig. 4. Oscillograms of 1-min-sections of the song of species of Phaneroptera. A - P. falcata, B - P. nana, C-I - P. sparsa: C-F Príncipe population: $C$ - calling song, $D$ - calling song with female response eliciting sound (FRES; marked by red lines), E-F - calling song with parts of FRES and $50-\mathrm{kHz}$-syllables (light blue), G - Tanzania, Kidia population, calling song with parts of FRES and 50-kHz-syllables (light blue), $\mathrm{H}-\mathrm{I}$ - Tanzania, Minziro population: $\mathrm{H}-$ calling song, I - calling song with FRES.

sparsa from Minziro, Tanzania). These single syllables are similar in the three species (Fig. 3; Table 2), especially in terms of the duration of the syllables. After the syllables in P. falcata and P. nana (but not in P. sparsa) sometimes microsyllables were recorded (e.g. Fig. 3E, I), which are probably imitations of the female's response (see Heller et al., 2020). They are produced by opening movements with a low amplitude (Fig. 3E). The syllable periods are generally quite variable, but the song of $P$. sparsa was mostly faster than that of the two other species. The impulse periods are typically longest in $P$. nana. Each impulse is probably produced by the contact of one tooth of the file with the scraper. This assumption is supported by the observation of occasional double impulses in the isolated syllables of $P$. bivittata, which has a much higher tooth density (Fig. 3B, Table 1). These impulses may be produced by neighbouring teeth.

Despite these single syllables being similar, the reaction of females differ distinctly between species. Since the males of falcata and sparsa produce additional sound elements, the species are treated separately.

\section{Phaneroptera falcata}

It is well known (see e.g. Ragge \& Reynolds, 1998) that besides the 'normal' calling song consisting of isolated syllables (Figs 4A, 5A), from time to time (typically at intervals of several minutes) the males of $P$. falcata produce fast series of syllables (echemes; SRR about $10 \mathrm{~Hz}$ ). Our recordings confirmed this. The syllables of these echemes, 

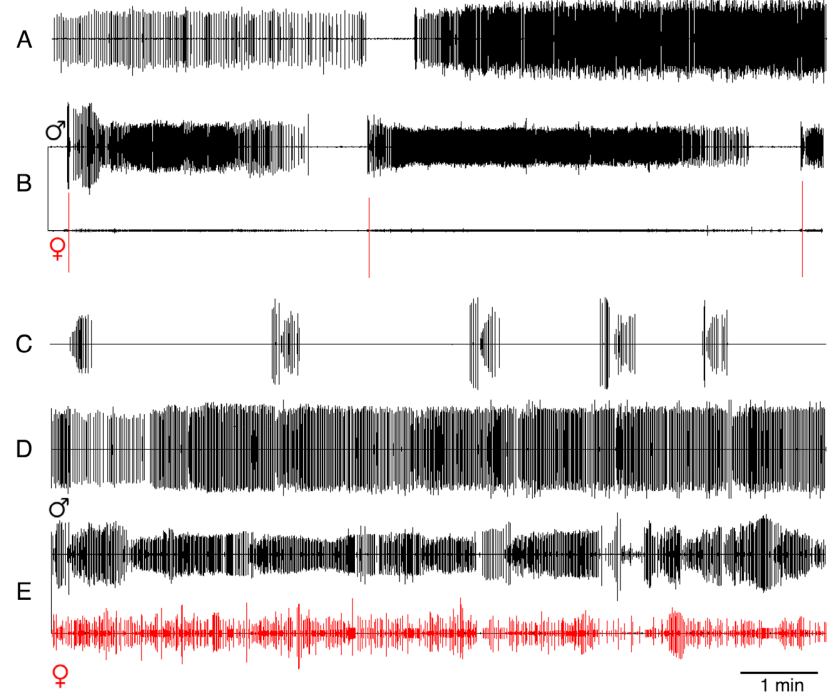

$1 \mathrm{~min}$

Fig. 5. Oscillograms of 10-min-sections of the song of species of Phaneroptera. A-B - P. falcata: A - spontaneous song of an isolated male, $\mathrm{B}$ - duet. $\mathrm{C}-\mathrm{E}-P$. nana: $\mathrm{C}$ - spontaneous song of an isolated male, $\mathrm{D}$ - song of an isolated male after acoustical contact with a female, E - duet.

which are also present in the song of this species in Korea (Kim, 2009) and Japan (Ichikawa et al., 2006), were slightly longer than isolated syllables and contained more impulses (Table 2). The females responded nearly exclusively after the echemes (Fig. 6A) and answered 1.9 $\pm 0.3 \mathrm{~s}$ after the beginning of the echeme and $0.46 \pm 0.15 \mathrm{~s}$ after the end (11 females, 11-15 measurements each). Each answer contained $1.9 \pm 0.4$ impulses at periods of $198 \pm 132 \mathrm{~ms}$ (see Fig. 6A, B). The males produced echeme-like series also by reducing the intervals between syllables, to which females occasionally responded (Fig. 6B). After a response, the male did not change its behaviour. A typical situation is illustrated by the recording in Fig. 5B. After a silent interval, the male produced an echeme, which was answered by the female. Then for several minutes the male continued with its calling song consisting of isolated syllables, until the whole sequence was repeated. Occasionally females also produced impulses during the series of isolated syllables, but this happened at most only once per few minutes (Fig. $6 \mathrm{C}$ ). In this example the female answered nearly exactly when the male produced a microsyllable (only produced by some males). Out of 10 females, two never answered during the series, six did with different frequencies (from very rare to sporadically) and two reacted only during the series. The response occurred $0.83 \pm 0.39 \mathrm{~s}$ (range $1-2309$ $\mathrm{ms}$ ) after the beginning of the single syllable or $2.27 \pm 0.85$ $\mathrm{s}$ (range 475-5129 $\mathrm{ms}$ ) after beginning of the preceding syllable ( 8 females, 1-22 measurements each). As after the response to an echeme, the males did not change their behaviour. However, quite often the male seemed to respond by increasing the syllable period by some ten milliseconds, which probably indicates he has heard her response. But rhythm and amplitude of the calling song did not change indicating that the male had not moved. The male's behaviour did not differ depending on the intensity of the
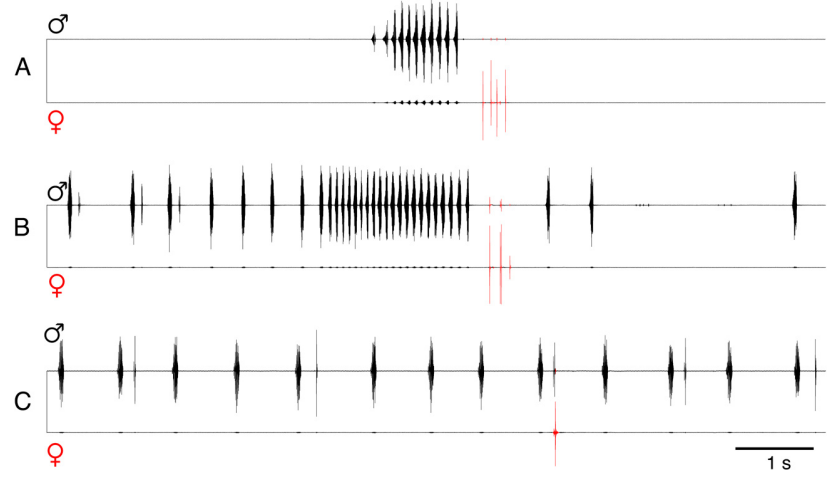

Fig. 6. Oscillograms of male songs and female responses for $P$. falcata (see text for details).

female's response, i.e. if the tubes containing the males and females were separated by a few centimetres or a few meters.

Remarkably, two males, whose singing activity was checked every night after the adult moult, started their calling activity by producing only echemes. On the first night the males produced 1 to 3 echemes per $h$. The next night and in the presence of a female, which responded to all his echemes, one male produced about 1 echeme per $10 \mathrm{~min}$ (for $2 \mathrm{~h}$ ), but switched only 4 times for short periods (20 s) to the normal calling song with isolated syllables. The other male's song initially consisted of a 30 min series of isolated syllables, later and the next night it consisted of only echemes ( 1 per $30 \mathrm{~min}$ for $3 \mathrm{~h}$; in the absence of a responding female). The following night it started again with a series of isolated syllables for $15 \mathrm{~min}$, but continued with only echemes, which were regularly answered by the female. Only the next night did he produce the typical song with echemes and series of isolated syllables nearly continuously for $4 \mathrm{~h}$ (in the absence of a responding female).

\section{Phaneroptera nana}

The acoustical behaviour of this species is described by several authors (see e.g., Ragge \& Reynolds, 1998) and studied experimentally by Zhantiev \& Korsunovskaja (1986, 1990) and Tauber and co-workers (Tauber \& Pener, 2000; Tauber, 2001; Tauber et al., 2001). Our results are in line with their data. Phaneroptera nana males only produce series of isolated syllables. Sequences of syllables can be heard at intervals of minutes (Fig. 5C), which is typical for isolated males, but they can also be many minutes long (Fig. 5D) or even more than an hour (up to $160 \mathrm{~min}$ in the absence of a response from a female). The syllable repetition rate is quite variable. As in the other species, parameters like duration of syllables and number of impulses per syllable were relatively variable (Table 2 ). Here we confirm older data (Heller, 1988) that there are frequently two different subtypes of syllables clustered together. Quite often a sequence started with dense (more impulses, short impulse periods) syllables (Fig. 3G) with slightly higher amplitude than the following sparse (few impulses, large impulse periods) syllables (Fig. $3 \mathrm{H}$; for an overview see Fig. 4, also visible in Fig. 5C). Also, the amplitude of the 

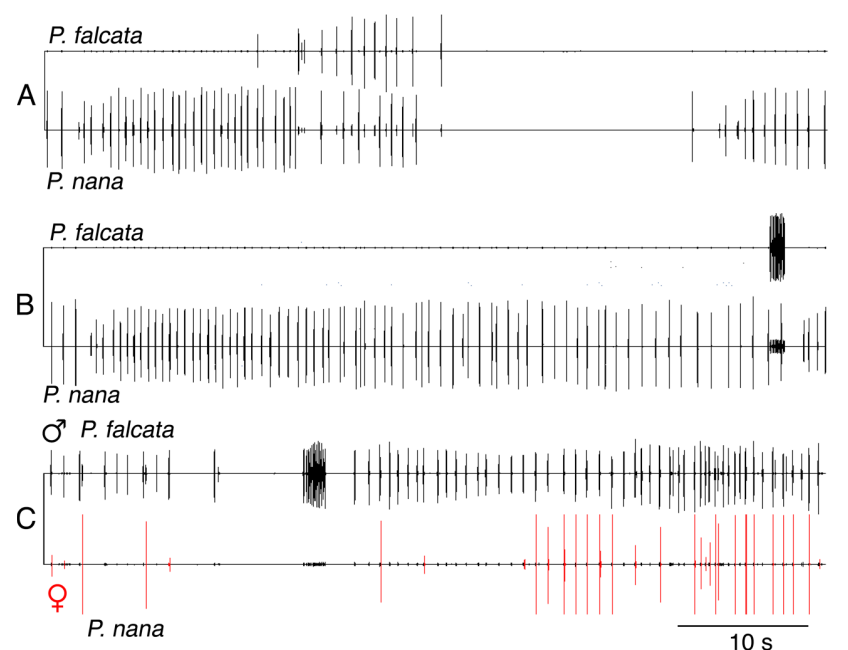

Fig. 7. Oscillograms of acoustical interactions between $P$. falcata and $P$. nana. A - P. falcata, attempts' to produce a series of single syllables, $B-P$. falcata produces an echeme during a less dense part of the song of $P$. nana without obvious effect. $C-A$ female of $P$. nana responds to the song of $P$. falcata.

stridulatory movements is often smaller in the sparse than in the dense syllables (see Heller 1988, fig. 20D, E). After some (dense) syllables occasionally one or two microsyllables were recorded (Fig. 3E, I). Females responded to both subtypes of syllable (Fig. 3G, H) and continued to answer for quite long periods (Fig. 5E). The latency of the response varied between $84.2 \pm 12 \mathrm{~ms}$ and $107.0 \pm 24 \mathrm{~ms}$ ( 2 females, 20 measurements each; measured from the first impulse) and when measured from the loudest impulse between $38.1 \pm 9 \mathrm{~ms}$ and $44.9 \pm 15 \mathrm{~ms}$.

\section{Acoustical interactions between $P$. falcata and $P$. nana}

Since the male songs of these two species are similar it is likely that these species will react to one another's songs. In a long test with two males singing side by side the Phaneroptera nana male was less influenced by the song of $P$. falcata than the reverse. The P. nana male sang nearly continuously for three hours while $P$. falcata produced only ten echemes during this time (Fig. 7A). Several times the $P$. nana male resumed its song shortly after falcata produced a series of isolated syllables (Fig. 7B). Interestingly, a $P$. nana female responded quite regularly to the isolated syllables of a $P$. falcata male, but not to the echemes produced by this animal (Fig. 7C). The latency of the response was $84.9 \pm 29 \mathrm{~ms}$ (from the loudest impulse $50.7 \pm 18 \mathrm{~ms} ; 20$ measurements recorded for 1 female), which did not differ from its response to the P. nana song (see above).

\section{Phaneroptera sparsa}

As in the other two species, isolated syllables were the most frequently recorded sounds for $P$. sparsa. In structure (duration, impulse number and intervals) these syllables are similar to those of $P$. falcata. However, they were produced at a higher rate (Table 2). Fast groups with a very variable number of syllables were separated by larger gaps (Fig. 4C). The time periods for which these groups of syllables were produced varied greatly. They ranged from a

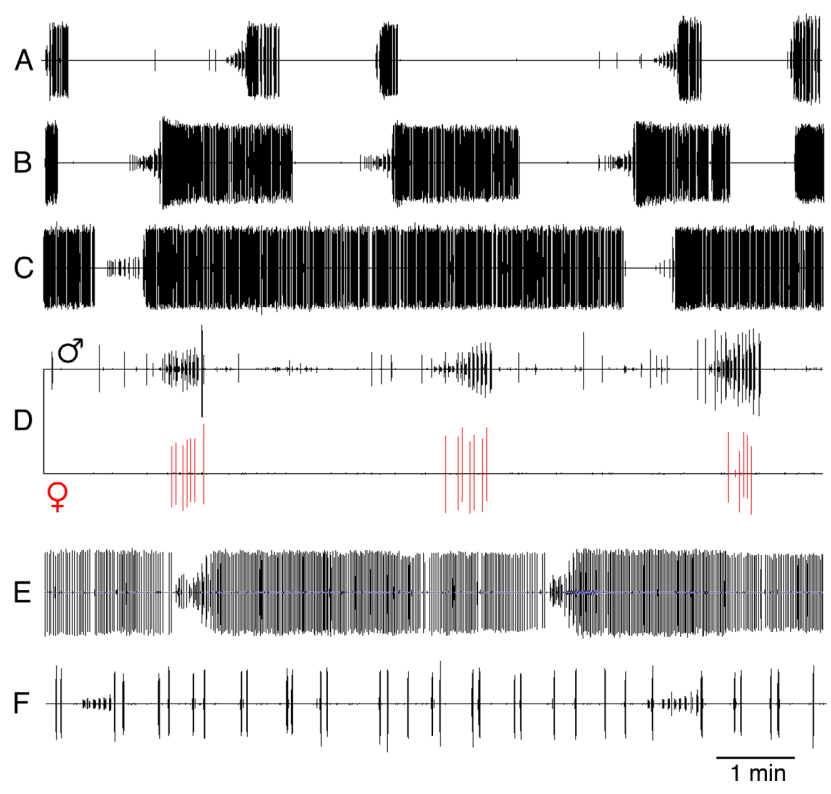

Fig. 8. Oscillograms of 10 -min-sections showing the variability in the song of male $P$. sparsa. A-C - differences in song frequency of isolated males from Príncipe, D - duet recorded between pair from Príncipe, E - song of an isolated male from Kidia, Tanzania, $\mathrm{F}$ - song of an isolated male from Minziro, Tanzania.

few seconds up to at least $2 \mathrm{~h}$ of uninterrupted singing (see examples in Fig. 8A-C). Only in the male from Minziro were these groups replaced by echemes (Table 2), which followed each other at intervals of many seconds (Fig. 4G). In terms of syllable structure (Fig. 3L) they did not differ from the single syllables produced by the males from Príncipe. However, all males from Tanzania had shorter syllables with fewer impulses and longer syllable periods (Table 2; see Fig. 8C, E).

Despite the common occurrence of isolated syllables females never or only extremely rarely responded to them. However, the males had additional types of songs that were produced more rarely than isolated syllables. These additional sounds were grouped into two categories according to their spectral properties. The first category contains 50-kHz-syllables (see A above). We have only limited information on these syllables because they were not recorded by the audio microphones. They were produced in the ultrasound range by all the males (from Príncipe and both localities in Tanzania) studied. The syllable periods (ca. 40-50 ms), durations (ca. 5-10 ms) and impulse periods (often $<1 \mathrm{~ms}$ ) were much shorter than those of isolated syllables (compare Figs $3 \mathrm{~K}-\mathrm{L}$ to $9 \mathrm{~F}$ ), but these syllables were also mostly softer than the isolated syllables (Fig. $4 F$ ). Typically, they were found in small groups of about three (rarely up to ten) occurring together with sounds of the second category (Fig. 4E, G), but did not seem to be directly connected to female responses. Sometimes they were found between series of single syllables. We have a hypothesis about their production, and an idea about their function (see Discussion). The second category contains sounds, which based on our recordings can be described as female response eliciting sounds (FRES; Fig. 9). In function they are thus similar to the "female tick elicitor", 

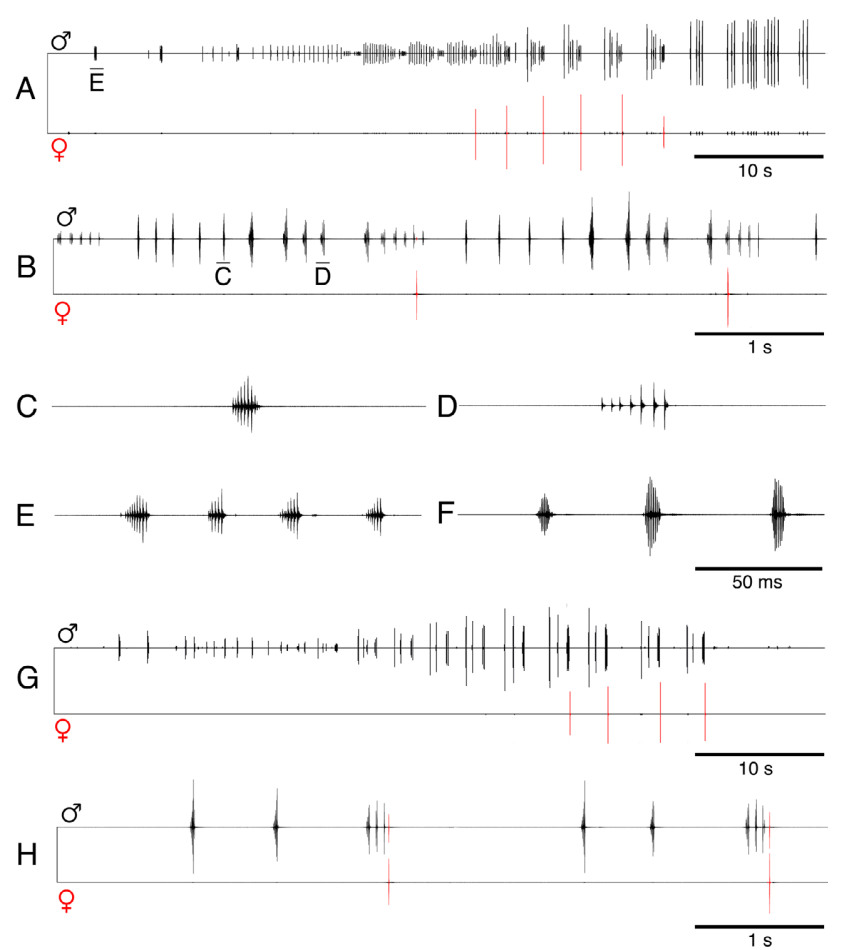

Fig. 9. Oscillograms of male song and female responses in $P$. sparsa. A-F - animals from Príncipe, G-H - animals from Kidia, Tanzania. A-B, G-H - duet recorded at different time scales, C - short dense syllable (SDS), D - short sparse syllable (SPS), E - group of SDS-like syllables, F - group of $50-\mathrm{kHz}$-syllables.

reported in North American phaneropterines by Spooner (1995), but here not one sound is involved but a complex group of syllables part of which is a tick elicitor sensu stricto. These syllables are softer than the single syllables and are produced only at intervals of several minutes (to hours). FRES were often heard at the beginning of a series of single syllables (Fig. 8) and were composed of several similar units. A unit typically started with a series of short $(13.5 \pm 2.1 \mathrm{~ms}$; range $9-18 \mathrm{~ms} ; \mathrm{n}=19$ males; all measurements from animals from Príncipe) syllables (Fig. 9C) with a relatively high impulse number (11.2 \pm 3.1 ; range $7-18 ; \mathrm{n}=17$ males), called short dense syllables (SDS), with syllable periods of $290 \pm 152 \mathrm{~ms}$ (range 123-678 ms; $\mathrm{n}=17$ males). Impulse periods were quite short $(1.4 \pm 0.3$ ms; range $0.7-1.9 \mathrm{~ms} ; \mathrm{n}=19$ males). The length of a series varied greatly, from 1 to more than 25 syllables and in their positioning in the series. The first units typically had more SDSs than the following and in the last units they were even often missing completely. Before typical FRES were recorded isolated groups of SDS-like syllables were often recorded at intervals of several (to many) seconds (Fig. 9E). In these groups the SRR was quite high (20-30 $\mathrm{Hz}$ ). After a series of typical SDSs (which occasionally were completely missing) a series of differently structured syllables followed, which were characterized by distinctly longer impulse periods (Fig. 9D; $4.3 \pm 0.7 \mathrm{~ms}$; range $3.3-$ $5.7 \mathrm{~ms} ; \mathrm{n}=19$ males). Since they were shorter than the single syllables they were called short sparse syllables (SPS). Their duration decreased from $35.1 \pm 8.4 \mathrm{~ms}$ (range 21-51 $\mathrm{ms} ; \mathrm{n}=19$ males) with $9.2 \pm 2.4$ (range 5-13) impulses to
$6.8 \pm 3.4 \mathrm{~ms}$ (range 1-11) with $1-2$ impulses $(1.8 \pm 0.4)$. At the beginning the syllable periods were around $200 \mathrm{~ms}$ ( $213 \pm 43 \mathrm{~ms}$, range 142-299 ms). The last group with the shortest syllables was separated from the preceding by a slightly longer gap. Female responses were nearly exclusively recorded during this last group, nearby but not with a clear relation in time to the syllables. They were recorded during, shortly after or shortly before a male syllable, rarely also around $80-90 \mathrm{~ms}$ after the last syllable. The male syllable periods ranged from 70 to $131 \mathrm{~ms}(86.1 \pm 14 \mathrm{~ms})$ in this period.

Compared to the immediately following isolated syllables, the intensity of the SDSs was $12.9 \pm 3.1 \mathrm{~dB}$ lower (mean $\pm \mathrm{SD}$ of $\mathrm{dB}$ values; range $8.9-18.2 \mathrm{~dB} ; \mathrm{n}=16$ males), whereas the final SPSs were even $20.3 \pm 4.2 \mathrm{~dB}$ softer (range 13.4-27.2; $\mathrm{n}=17$ males). However, as soon as a male heard a female's response, it typically did not produce isolated syllables anymore, but switched to sequences of FRES (Fig. 8D; but see Fig. 9A for an exception).

The animals from Kidia and Minziro also produced similar patterns of SDSs and SPSs (see Figs 8, 9), but differed in the number of these syllables and their amplitude.

\section{C) Intensity}

For a few specimens the loudness of the song was measured using a sound level meter in order to estimate the distance over which they can communicate and for comparison with other species. For two males of P. nana the value was $62 \mathrm{~dB}$ SPL at a distance of $1 \mathrm{~m}$ (male 1: $61.8 \pm 2.6$ $\mathrm{dB}, \mathrm{n}=10$; male $2: 62 \pm 0.8 \mathrm{~dB} ; \mathrm{n}=10$ ). The responses of female $P$. nana were very variable, but always clearly softer (ca. $46 \mathrm{~dB}$ SPL at $1 \mathrm{~m}$ ) than the song of the male. For $P$. falcata, the mean for six males was $57.8 \pm 1,4 \mathrm{~dB}$ SPL ( $\mathrm{n}=10$ measurements per male). However, since the peak frequency of this species is above $20 \mathrm{kHz}$ and thus outside the linear range of the meter, the results can only be used as an indication that the sound pressure may be similar in range as in P. nana.

\section{D) Behaviour}

In one of the video recordings of $P$. falcata the approach phase of the sexes and the following mating was documented. The female approached the quietly sitting male by jumping and walking, probably guided by the male's song, until antennal contact.

\section{DISCUSSION}

As to be expected from typical phaneropterine mating behaviour (Heller et al., 2015), the females of all three species of Phaneroptera responded acoustically to the song of males. However, the male calling songs are not markedly different, which is surprising for widespread and partly sympatric species. The males of all three species produced a series of isolated syllables (Figs 3, 4). Despite the similarity of the songs of the males, communication and mate localization differed distinctly. Spooner (1995) reviewed pair-forming strategies of North American phaneropterines, documenting four types. Males may move all the way towards answering females (type 1), or both sexes 
move (types 2-4). In all three (sub)types of the latter category the male song contains independent elements with different functions (Spooner, 1995) although in one type (both sexes move to similar extents) both elements may be combined in a fixed sequence. In Europe, the mute females of many species of Poecilimon represent a fifth type, in which females approach phonotactically immobile singing males (see e.g., Heller, 1992; Strauß et al., 2014). The few other phaneropterine species with mute females around the world (e.g., Ingrisch et al., 2021) also use this strategy.

The mating strategy of Phaneroptera nana seems to be closest to the first type of pair-forming (male approaches immobile female), as is also reported by Roesti \& Keist (2009). Though the male produces two different types of syllable, the females respond to both of them. To attract a response, a male syllable must contain at least two impulses (Zhantiev \& Korsunoskaya, 1986), separated by an interval of 5-30 ms (Tauber \& Pener, 2000). This condition is obviously also met by the syllables of $P$. falcata which are also answered by the females of $P$. nana (Fig. 7C). In choice tests with conspecifics, females responded preferentially to males producing syllables with a high number of impulses (Tauber et al., 2001). The preference for larger males reported in the same paper may be based on song intensity (not measured). Males approached only females responding with a high rate (Tauber et al., 2001). For this pair-forming strategy, the song intensity of both sexes should be similar (assuming the hearing ability of both sexes is similar) otherwise beyond a certain distance the sex with the lower intensity song would not be heard by the other. We confirmed the relatively low intensity of the male song of $P$. nana (see Helversen et al., 2015, table 1) and also the even lower intensity of the female response reported by Tauber et al. (2001). However, females responding to quite distant males and a restricted range of male phonotaxis do not seem to be unusual in phaneropterines (see discussion in Helversen et al., 2015). Changes in sound intensity during the phonotactic approach, as described by Roesti \& Keist (2009), seem to be plausible but could not be studied under our conditions.

Surprisingly, on the other hand, the pair-forming strategy of Phaneroptera falcata (female approaches immobile male) is closest the fifth type. The females responded preferentially to the echemes in the male song (Fig. 5B), but after their response the males did not change their singing behaviour. Typically, neither song rhythm nor song amplitude was affected, indicating that the male continued to sing without approaching phonotactically. The male did not repeat the echeme to obtain more information about the position of the female. Even if a female responded to a single syllable (Fig. 6), the male song did not change except for a very slightly enlarged syllable period after the response. Since in our recording setup males and females were often close together the possibility that the male had not heard the female can be excluded. Also, the video recording documented the female's approach. One may argue that at greater distances the male possibly approaches the female as proposed in Spooner's (1995) strategy “2". How- ever, when a male and a female were placed $2 \mathrm{~m}$ apart, the behaviour of the male did not change. In addition, it would be difficult for a male to find a female that rarely responds. $P$. falcata female responses are not only rarely recorded in our study. Roesti \& Keist (2009) state explicitly that they have never recorded responses of female falcata, but present such recordings for nana in their book and CD as does Bonnet (1995). Only Samietz et al. (2014) describe female responses, but they do not seem to know that $P$. falcata has different types of song. So, for us it is a more plausible that by responding the female may stimulate the male to continue singing instead of informing him about her location although he may be able to use it. Only one feature of the male acoustical behaviour of $P$. falcata remains unexplained, that is the function of the microsyllables (Fig. 6). Very short sounds produced at the time of female response are relatively common in phaneropterine songs (see Heller \& Hemp, 2020; Heller et al., 2020). They are thought to be a defence against eavesdropping rivals, which is easily understandable for P. nana (see Fig. 3E, I) and unnecessary and missing in P. sparsa (see below), but does not make sense for falcata if only the female moves. Are they relicts of former male approach behaviour?

Phaneroptera sparsa has a more complicated pair-forming strategy similar to one of Spooner's (1995) types in which both sexes move. From time to time in periods that can last several to many minutes the male inserts special sequences in his long calling song. We have called this part of the song the female response eliciting sound (FRES). These sounds are much softer than the typical calling song and can be heard and answered only by nearby females. Probably the female uses the period of normal song to approach him. The other possibility is that he moves, which seems less probable, especially when compared to Horatosphaga heteromorpha (Karsch). Males of this species move, sing a few times at one place and move to the next singing post (Hemp et al., 2018). P. sparsa males sing for a long period of time from one place without moving, as can be concluded from its long songs without changes in amplitude (e.g., Fig. 8). If a male hears a response, it discontinues the normal song and exclusively uses FRESs, probably to obtain more responses and more information about the position of the female in order to quickly find her. The FRESs contain two different types of syllable. Both (SDS and SPS) may be related to the correct placement of the response and protection against eavesdropping rivals although how this achieved is unknown. Near to FRES often 50-kHz-syllables have been observed.. Sounds with different carrier frequencies in the song of one species are uncommon but produced by some species. For the production of different carrier frequencies often a two part stridulatory file is used (see review in Heller \& Hemp, 2017). In species of Phaneroptera the male file typically has a clearly separated distal part (see Introduction, Fig. 1) with smaller teeth and a higher tooth density than on the main part. We assume that this part is used for the production of high frequency syllables with correspondingly small impulse intervals. But what is the function of these relatively soft 
and not far reaching sounds? In lebinthine crickets (Lebinthini, Eneopterinae, Gryllidae), the males produce unusually high frequency calling songs, which are answered by females with vibrations (ter Hofstede et al., 2015). The authors assume that this behaviour evolved from an acoustic startle behavioural response to high-frequency sounds. Perhaps $P$. sparsa females react also with vibratory signals to the male $50 \mathrm{kHz}$ syllables, which are similar to bat calls in frequency and intervals (see e.g., Surlykke et al., 2016).

Obviously the three species studied differ not so much in the amplitude modulation of their calling songs, but in the structure and details of the duetting behaviour. Even the unusual echeme motive, seemingly characteristic of P. falcata, is present in the song of a male in a population of $P$. sparsa from East Africa. The songs of other species of Phaneroptera are partly similar (e.g., P. gracilis, Thailand; Ingrisch, 2020), partly the amplitude modulation may be more complex (e.g., P. cleomis; Ayal et al., 1973; P. spinosa; Korsunovskaya, 2008; P. nigroantennata; Kim, 2009). However, all three pair-forming strategies are not unique but are reported in other phaneropterine genera (see Spooner, 1995). At present the forces driving the evolution of these strategies are unknown. They are probably associated with intraspecific processes and have nothing to do with species recognition. They may be connected with ecological factors, which influence density and synchronization of populations. P. sparsa is a non diapausing tropical species in which adults and nymphs of all sizes occur together (Heller, 2019), whereas P. falcata and nana are univoltine in temperate regions. Also, the mating behaviour may differ as indicated by the different sizes of the spermatophores. The females of $P$. falcata with the potentially risky phonotactic approach (e.g., Heller, 1992) receive much larger spermatophores than $P$. nana and P. sparsa (Vahed, 1994; Heller, 2019) in which the males move. Detailed ecological studies, especially in areas where two species occur sympatrically may reveal the advantages of the different strategies.

ACKNOWLEDGEMENTS. We thank K. Mosny for his help in collecting animals, G. Köhler for access to the data of the late J. Samietz and comments on an earlier version of the manuscript and to two anonymous reviewers for helpful comments.

\section{REFERENCES}

Ayal Y., Broza M. \& Pener M.P. 1973: A new species of the genus Phaneroptera Serville (Orthoptera: Tettigoniidae) from southern Israel and Sinai with some data on its biology. - Israel J. Zool. 22: 83-96.

Barataud M. 2007: Sauterelles de la France Moyenne. Edition Sittelle. Compact Disc.

Bei-Bienko G.Y. 1954: Phaneropterinae. Fauna of the USSR, Orthoptera Vol. II, Nr. 2. Moskva, Leningrad. Israel Program for Scientific Translation, Jerusalem, 1965, 381 pp.

BonNET F.R. 1995: Guide sonore des sauterelles, grillons et criquets d'Europe occidentale. Delacheaux \& Nestlé, LausanneParis, Compact Disc.

Brunner von Wattenwyl C. 1878: Monographie der Phaneropteriden. Brockhaus, Wien, $401 \mathrm{pp}$.
Chamorro-Rengifo J., Braun H. \& Lopes-Andrade C. 2014: The secret stridulatory file under the right tegmen in katydids (Orthoptera, Ensifera, Tettigonioidea). — Zootaxa 3821: 590-596.

Deroussen F. 2012: Le chants de sauterelles de France. Naturophonia, Compact Disc.

Divya G. \& Senthilkumar N. 2020: Contribution to the knowledge of the genus Phaneroptera (Tettigoniidae: Phaneropterinae) with a new record from Tamilnadu, India. - Zootaxa 4860: 425-434.

FIEBER F.X. 1853: Synopsis der europäischen Orthopteren mit besonderer Rücksicht der böhmischen Arten. - Lotus 3: 90-104, 115-131, 138-154, 168-176, 184-188, 201-207, 232-238, 252-261.

Gomboc S. \& Šegula B. 2014: Singing Orthoptera of Slovenia. EGEA, Zavod za naravo, Ljubljana, 240 pp. + Compact Disc.

Harz K. 1969: Die Orthopteren Europas / The Orthoptera of Europe I. Springer Netherlands, The Hague, $749 \mathrm{pp}$.

Helfert B. \& Sänger K. 1990: Fortpflanzung und Fortpflanzungsbarrieren bei Phaneroptera nana Fieb. (1853) und Phaneroptera sparsa Stål (1857) (Orthoptera: Tettigonioidea). Zool. Jb. Syst. 117: 109-116.

HELLER K.-G. 1988: Bioakustikder europäischen Laubheuschrecken. Margraf, Weikersheim, $358 \mathrm{pp}$.

Heller K.-G. 1992: Risk shift between males and females in the pair-forming behavior of bushcrickets. - Naturwissenschaften 79: 89-91.

Heller K.-G. 2019: Provisional checklist of the Tettigonioidea (Insecta: Orthoptera) from São Tomé \& Príncipe with taxonomic remarks, bioacoustical data and the description of new taxa. - Zootaxa 4563: 41-66.

Heller K.-G. \& Hemp C. 2017: Context specific signaling with different frequencies - directed to different receivers? A case study in Gonatoxia katydids (Orthoptera, Phaneropteridae). J. Insect Behav. 30: 420-431.

Heller K.-G. \& Hemp C. 2020: Hyperdiverse songs, duetting, and the roles of intra- and intersexual selection in the acoustic communication of the genus Eurycorypha (Orthoptera: Tettigonioidea, Phaneropterinae). — Org. Divers. Evol. 20: 597-617.

Heller K.-G., Hemp C., Ingrisch S. \& Liu C.-X. 2015: Acoustic communication in Phaneropterinae (Tettigonioidea) - a global review with some new data. - J. Orthopt. Res. 24: 7-18.

Heller K.-G., KorsunovsKaya O.S., Massa B. \& Iorgu I.S. 2018: High-speed duetting - latency times of the female acoustic response within the bush-cricket genera Leptophyes and Andreiniimon (Orthoptera, Phaneropteridae). — Zookeys 750: 45-58.

Heller K.-G., Volleth M., Vedenina V., MaryańsKa-NadachowSKa A. \& WarchalowsKa-Śliwa E. 2020: A perfect duet? The acoustic behaviour of Anaulacomera almadaenis sp. nov., a species with an unusual chromosome complement, discovered in the footsteps of the explorers Spix and Martius in Brazil (Orthoptera, Tettigonioidea, Phaneropterinae). — Spixiana 43: $105-118$.

Helversen O. von, Helversen D. von, Rohrseitz K., Koopmann I., Stumpner A. \& Heller K.-G. 2015: Signals and sex-specific active space in a duetting insect (Orthoptera: Phaneropteridae: Poecilimon affinis). - J. Orthopt. Res. 24: 19-28.

Hemp C., Heller K.-G., Warchalowska-Śliwa E., Grzywacz B. \& Hemp A. 2018: New genera and new species of Acrometopini (Orthoptera: Tettigonioidea: Phaneropterinae) from East Africa and a review of all known stridulatory organs, songs and karyotypes of the tribe. - Insect Syst. Evol. 49: 241-298.

Hugel S. 2009: Gryllacrididae and Tettigoniidae (Insecta, Orthoptera, Ensifera) from Espiritu Santo, Vanuatu. - Zoosystema 31: 525-576. 
Ichikawa A., Kano Y., Kawai M., Tominago O. \& Murai T. (eds) 2006: Orthoptera of the Japanese Archipelago in Color. Hokkaido University Press, Sapporo, 688 pp. + Compact Disc [in Japanese].

Ingrisch S. 2020: Phaneroptera gracilis. In Cigliano M.M., Braun H., Eades D.C. \& Otte D.: Orthoptera Species File. Ver. 5.0/5.0. URL: http://Orthoptera.SpeciesFile.org

Ingrisch S., Heller K.-G., Warchalowska-Śliwa E. \& Liu C.-X. in press: On the biology of the high-altitude katydid Anormalous zhangi Liu, 2011 (Orthoptera, Tettigoniidae, Phaneropterinae) from Yunnan: Development, behavior, stridulation, chromosomes, systematics. In Hartmann M. \& Weipert J. (eds): Biodiversity and Natural Heritage of the Himalaya. Vol. VII. Naturkundemuseum Erfurt.

Iorgu I.S., Pisica E.I. \& PAIS L.M. 2008: The Orthoptera associations (Insecta: Orthoptera) from Letea Sand Bank and Sulina (Danube Delta Biosphere Reservation, Romania). - Brukenthal Acta Musei 3: 111-121.

KIM T.W. 2009: Taxonomy and Acoustic Signals of Korean Tettigonioidea (Orthoptera: Ensifera) II. National Institute of Biological Reserves, Incheon, 139 pp. + Compact Disc [in Korean].

KoČÁReK P., HoluŠA J., VlK R. \& Marhoul P. 2013: Orthopteran Insects (Insecta: Orthoptera) of the Czech Republic. Academia, Praha, 283 pp. + Compact Disc [in Czech].

KoRsunOvSKayA O.S. 2008: Acoustic signals in katydids (Orthoptera, Tettigonidae). Communication I. - Entomol. Rev. 88: $1032-1050$

LEROY Y. 1970: Diversités d'aspects et évolution de la dissymétrie des râpes de stridulation des insectes orthoptères Phaneropterinae. - C. R. Acad. Sci. 270: 96-99.

LiU C.-X. 2011: Phaneroptera Serville and Anormalous gen. nov. (Orthoptera: Tettigoniidae: Phaneropterinae) from China, with description of two new species. - Zootaxa 2979: 60-68.

Massa B., Buzzetti F.M. \& Fontana P. 2010: Order Orthoptera. - Arthropod fauna UAE 3: 70-112.

Massa B., Fontana P., Buzzetti F.M., Kleukers R.M.J.C. \& OdÉ B. 2012: Fauna d'Italia. 48. Orthoptera. Calderini, Milano, $563 \mathrm{pp}$.

Montealegre-Z F. 2012: Reverse stridulatory wing motion produces highly resonant calls in a neotropical katydid (Orthoptera: Tettigoniidae: Pseudophyllinae). - J. Insect Physiol. 58: $116-124$

NASKRECKI P. \& GutA R. 2019: Katydids (Orthoptera: Tettigoniidae) of Gorongosa National Park and Central Mozambique. Zootaxa 4682: 1-119.

Poda von Neuhaus N. 1761: Insecta Musei Graecensis, quae in ordines, genera et species juxta Systema Naturae Linnaei digessit. viii $+127+$ xii pp. [Orthoptera pp. 49-53]; Graecii [= Graz] [Facsimile edition W. Junk 1915, viii + 140 pp.].

Poniatowski D., Münsch T., Helbing F. \& Fartmann T. 2018: Range shifts of Central European Orthoptera as a response to climate change. - Natur und Landschaft 93: 553-561.

RaGge D.R. 1956: A revision of the genera Phaneroptera Serville and Nephoptera Uvarov (Orthoptera: Tettigoniidae) with conclusions of zoogeographical and evolutionary interest. - Proc. Zool. Soc. Lond. 127: 205-283.

RagGe D.R. 1960: Further notes on the genus Phaneroptera. Proc. Zool. Soc. Lond. 134: 237-250.

RaGGe D.R. 1980: A review of the African Phaneropterinae with open tympana (Orthoptera: Tettigoniidae). - Bull. Br. Mus. Nat. Hist. (Entomol.) 40: 67-192.

RaGge D.R. \& ReYNolds W.J. 1998: The Songs of the Grasshoppers and Crickets of Western Europe. Harley Books \& The Natural History Museum, London, 591 pp.
Roesti C.H. \& Keist B. 2009: Die Stimmen der Heuschrecken. Haupt, Bern, Stuttgart \& Wien, 144 pp. + Compact Disc.

Samietz J., Schumacher J. \& Reinhardt K. 2014: Comparison of the mating behaviour of a bush cricket in the laboratory and the field: Calling activity and mating frequency of a long-winged species, Phaneroptera falcata (Ensifera: Tettigoniidae). Eur. J. Entomol. 111: 180-197.

Serville J.G.A. 1831: Revue méthodique des insectes de l'ordre des Orthoptères. - Ann. Sci. Nat. (Zool. Biol. Anim.) 22: 2865; 134-167; 262-292.

SPOONER J.D. 1995: Pair-forming phonotaxis strategies of phaneropterine katydids (Tettigoniidae: Phaneropteridae). - J. Orthopt. Res. 4: 127-129.

STÅL C. 1856: Orthoptera cursoria and Locustina from Cafferlandet. - Öfvers. K. Vetensk.-Akad. Förh. (Stockholm) 13: 165-170 [in Swedish].

Stolyarov M.V. 2005: New data on distribution and taxonomy of the Orthoptera from Caucasus. 1. Stenopelmatoidea and Tettigonioidea. - Proc. Rus. Entomol. Soc. St. Petersburg 76: 62-71 [in Russian].

Strauss J., Lehmann A.W. \& Lehmann G.U.C. 2014: Sensory evolution of hearing in tettigoniids with differing communication systems. - J. Evol. Biol. 27: 200-213.

Stumpner A. \& Meyer S. 2001: Songs and the function of song elements in four duetting bushcricket species (Ensifera, Phaneropteridae, Barbitistes). - J. Insect Behav. 14: 511-534.

Surlykke A., Simmons J.A. \& Moss C.F. 2016: Perceiving the world through echolocation and vision. In Fenton M.B., Grinnell A.D., Popper A.N. \& Fay R.R. (eds): Bat Bioacoustics. Springer Handbook of Auditory Research, Vol. 54, New York, pp. 265-288.

TAUBER E. 2001: Bidirectional communication system in katydids: the effect on chorus structure. - Behav. Ecol. 12: 308312.

TAuber E. \& Pener M.P. 2000: Song recognition in female bushcrickets Phaneroptera nana. - J. Exp. Biol. 203: 597-603.

Tauber E., Cohen D., Greenfield M.D. \& Pener M.P. 2001: Duet singing and female choice in the bushcricket Phaneroptera nana. - Behaviour 138: 411-430.

ter Hofstede H.M., Schöneich S., Robillard T. \& Hedwig B. 2015: Evolution of a communication system by sensory exploitation of startle behavior. - Curr. Biol. 25: 3245-3252.

VAHED K. 1994: The Evolution and Function of the Spermatophylax in Bushcrickets (Orthoptera: Tettigoniidae). Ph.D Thesis. Nottingham University, Nottingham, 227 pp.

WiLlemse L.P.M., KLEUKERS R.M.J.C. \& OdÉ B. 2018: Grasshoppers of Greece. EIS Kenniscentrum Insecten \& Naturalis Biodiversity Center, Leiden, 440 pp.

ZhantIEV R.D. \& KorsunOvSKAYA O.S. 1986: Sound communication in bush crickets (Tettigoniidae, Phaneropterinae) of the European part of the USSR. - Zool. Zh. 65: 1151-1163 [in Russian].

Zhantiev R.D. \& KorsunOvsKaya O.S. 1990: Sound communication of Phaneropteridae (Orthoptera). In Gribakin F.G., Wiese K. \& Popov A.V. (eds): Advances in Life Sciences: Sensory System and Communication in Arthropods. Birkhäuser, Basel, pp. 403-406.

ZunA-Kratky T. 2017: Vierpunktige Sichelschrecke Phaneroptera nana Fieber, 1853. In Zuna-Kratky T., Landmann A., Illich I., Zechner L., Essl F., Lechner K., Ortner A., Weißmair W. \& Wöss G.: Die Heuschrecken Österreichs. — Denisia 39: 208-211.

Received January 26, 2021; revised and accepted March 8, 2021 Published online April 1, 2021 


\section{Appendix}

Phaneroptera falcata (Poda, 1761): CH0404; GERMANY:

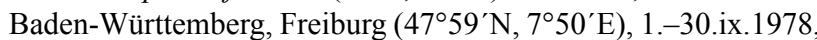
eg. Heller. CH0707; GERMANY: Bayern, Maintal nordwestl. Bamberg $\left(49^{\circ} 58^{\prime} \mathrm{N}, 10^{\circ} 43^{\prime} \mathrm{E}\right), 1 .-31 . x .1981$, leg. Heller. CH7010; POLAND: Bieszczady, Wolosate (49 $\left.4^{\prime}{ }^{\prime} \mathrm{N}, 22^{\circ} 41^{\prime} \mathrm{E}\right)$, 18.vii.2007, leg. Beata Grzywacz. CH7402; ROMANIA: Parângului Mountains, Crasna, 16.viii.2011, leg. Nadachowska. CH8589; GERMANY: Sachsen-Anhalt, Gegensteine bei Ballenstedt $\left(51^{\circ} 44^{\prime} \mathrm{N}\right.$,

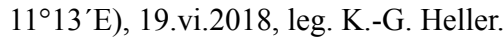

Phaneroptera nana Fieber, 1853: CH0713; SPAIN: Barcelona, Riera Martes westl. Vic $\left(41^{\circ} 47^{\prime} \mathrm{N}, 2^{\circ} 16^{\prime} \mathrm{E}\right), 10 . i x .1979$, leg. Heller \& Volleth. CH0715; ITALY: Lazio, Sabaudia südl. Rom $\left(41^{\circ} 17^{\prime} \mathrm{N}, 13^{\circ} 1^{\prime} \mathrm{E}\right)$, 1.i.-31.xii.1980, leg. R. Hess. CH5489; TURKEY: Mugla, Turgut (bei Wasserfall) (ca. $16 \mathrm{~km}$ sw Marmaris) $\left(36^{\circ} 44^{\prime} \mathrm{N}, 28^{\circ} 7^{\prime} \mathrm{E}\right)$, 8.vi.2000, leg. K.-G. Heller. CH6385; GREECE: Khalkidhiki, Koutloumousi southeast of Vourvourou (camp site Lacara) on Sithonia ( $\left.40^{\circ} 10^{\prime} \mathrm{N}, 23^{\circ} 51^{\prime} \mathrm{E}\right), 2 \mathrm{~m}, 19 .-20$ vii.2004, leg. K.-G. Heller \& M. Heller. CH8705; GERMANY: Baden-Württemberg, Heidelberg, 28.vii.2018, leg. M. Heller.

Phaneroptera sparsa Stål, 1857: CH4958; NAMIBIA: Fischfluß-Canyon bei Ai-Ais (heiße Quellen) $\left(27^{\circ} 54^{\prime} \mathrm{S}, 17^{\circ} 28^{\prime} \mathrm{E}\right)$, 27.x.1996, leg. A. (Wendler) \& G. Lehmann. CH8685; TANZANIA: Northern part, Mount Kilimanjaro, Kidia, 1.-31.iii 2019, leg. C. Hemp. CH8561; SAO TOME \& PRINCIPE: Principe, near Bom Bom Island Resort ( $\left.1^{\circ} 41^{\prime} \mathrm{N}, 7^{\circ} 24^{\prime} \mathrm{E}\right), 20 \mathrm{~m}, 24 .-27$. iv.2018, leg. M. \& K.-G. Heller \& Marianne Volleth. CH4957; MADAGASCAR: Perinet / Andasibe 90 km östl. Antananarivo (1858'S, 48²4'E), 20.iii.1991, leg. A. Meschede. CH5002; ZAIRE / CONGO: Kivu, Irangi (ca.100 km westl. Bukavu) Centre de Recherche en Sciences Naturelles ( $\left.1^{\circ} 54^{\prime} \mathrm{S}, 28^{\circ} 27^{\prime} \mathrm{E}\right)$, 13.-25.iii.1990, leg. K.-G. Heller \& M. Volleth.

Phaneroptera bivittata Bey-Bienko, 1954: CH0710; TURKEY: Erzurum, Coruh-Tal $35 \mathrm{~km}$ nö Ispir $\left(40^{\circ} 40^{\prime} \mathrm{N}, 41^{\circ} 16^{\prime} \mathrm{E}\right), 900 \mathrm{~m}$, 5.-6.viii 1983, leg. Heller. 